\title{
Bone metabolism dysfunction mediated by the increase of proinflammatory cytokines in chronic HIV infection
}

\author{
Erika Grasiela Marques de Menezes, ${ }^{1,4}$ Alcyone Artioli Machado² ${ }^{2}$ \\ Fernando Barbosa $\mathrm{Jr}^{3}{ }^{3}$. Francisco José Albuquerque de Paula ${ }^{2}$. \\ Anderson Marliere Navarro ${ }^{2}$
}

Received: 27 October 2015 / Accepted: 22 February 2016 / Published online: 29 March 2016

(C) The Japanese Society for Bone and Mineral Research and Springer Japan 2016

\begin{abstract}
Despite the efficacy of antiretroviral therapy (ART) on the control of viral replication, the current challenge is to decrease the chronic inflammatory status and toxicity of the antiretroviral drugs that contribute to increase the risk of metabolic complications. To verify the influence of proinflammatory cytokines on bone metabolism mediated by chronic HIV infection, a cross-sectional study was conducted with 50 HIV-infected adult men treated or not treated with ART. Dual energy X-ray absorptiometry (DXA) was performed to assess bone mineral density. Biochemical analysis were performed of IL-6, TNF- $\alpha$, osteocalcin, PTH, 25-OH-D, total calcium, albumin, $24 \mathrm{~h}$ urinary calcium, and urinary deoxypyridinoline. The participants not treated with ART exhibited higher values of IL-6 and TNF- $\alpha$ than the participants treated with ART for more than 2 years. The TNF- $\alpha$ values were higher in the participants treated with ART for $<2$ years than in participants treated with ART for more than 2 years $(p<0.05)$. The increased values of urinary deoxypyridinoline indicated
\end{abstract}

Erika Grasiela Marques de Menezes

erikagmm7@yahoo.com.br

1 Department of Food and Nutrition, Faculty of Pharmaceutical Sciences, University of São Paulo - UNESP, Araraquara, Brazil

2 Department of Internal Medicine, Ribeirão Preto Medical School, University of São Paulo - FMRP/USP, Ribeirao Preto, Brazil

3 Department of Clinical Analysis, Toxicological and Bromatology, Faculty of Pharmaceutical Sciences of Ribeirão Preto, University of São Paulo - FCFRP/USP, Ribeirao Preto, Brazil

4 Avenida Bandeirantes, 3900, Monte Alegre, Ribeirão Preto, SP 14049-900, Brazil a high reabsorptive activity of bone tissue in all groups, with a significant difference between the participants not treated with ART and the participants treated with ART for $<2$ years. Through the DXA we found a bone mass reduction in all bone sites in each group. The increase in production of proinflammatory cytokines, most notably in the viremic group, demonstrated the ability to stimulate osteoclast activity and subsequently affect bone mass. The reduction of bone mineral density was observed in all bone sites, principally for the groups receiving antiretroviral treatment.

Keywords HIV · ART - Proinflammatory cytokines · Bone mineral density $\cdot$ Urinary deoxypyridinoline

\section{Introduction}

The natural history of human immunodeficiency virus (HIV) infection and progressions in antiretroviral treatment (ART) are well evidenced by increases in the CD4+ T cell count, the reduction of viral replication, and the reduced risk for opportunistic infections. Despite the efficacy of ART, it carries certain repercussions such as the systemic effects of inflammation mediated by the chronic HIV infection and toxicity of the antiretroviral drugs, which significantly contribute to increasing the risk of metabolic complications. There is evidence that these complications are more common in HIV-infected adults than in uninfected people of the same age, suggesting that HIV leads to premature aging [1].

One of the aspects highlighted for premature aging is HIV-mediated chronic inflammation, which leads to persistent activation of the innate and adaptive immune systems associated with the release of proinflammatory cytokines, 
even after controlling the virus with ART. This leads to the abnormal function of lymphoid tissue and the emergence of various diseases that would manifest later in life [1, 2]. The release of proinflammatory cytokines, such as interleukin-6 (IL-6) and tumor necrosis factor- $\alpha$ (TNF- $\alpha$ ), and their increased levels, may interfere in bone metabolism and contribute to increased bone resorption $[3,4]$.

Simultaneously, the cumulative effect of HIV infection and the toxicity of the antiretroviral drugs contributes to mitochondrial dysfunction, which in turn increases the production of proinflammatory cytokines leading to an increase in osteoclast maturation and a decrease in osteoprotegerin, resulting in a reduction in bone mineral density (BMD) $[4,5]$. Additionally, other factors common in this group of patients can also contribute to bone loss, such as low body mass index, alcoholism, smoking, drug use, decreased calcium intake, physical inactivity, vitamin D deficiency, hypogonadism, and increased parathyroid hormone serum concentrations [6-9].

Importantly, the direct effects of chronic inflammation due to HIV may increase bone reabsorption, resulting in a negative bone balance [7]. Therefore, the elevation of inflammatory biomarkers mediated by chronic HIV infection and the toxicity of the antiretroviral drugs both influence metabolic disorders and increase the risk of morbidity and mortality $[8,9]$. This study aimed to verify the influence of proinflammatory cytokines on bone metabolism mediated by chronic HIV infection in patients undergoing antiretroviral treatment.

\section{Materials and methods}

\section{Recruitment, ethics, and general study design}

This cross-sectional study was performed with 50 adult men, all seropositive for HIV, with different viral load measurements and undergoing treatment or not with ART. The exclusion criteria considered were: use of calcium and vitamin D supplements, use of drugs active on bone and mineral metabolism, previous thyroidectomy, presence of renal and/or hepatic insufficiency, hypophosphatemia, hypogonadism, rheumatic diseases, and the presence opportunistic infection. The recruitment of the volunteers was conducted at the Clinical Hospital of the Ribeirão Preto Medical School, University of São Paulo (HCFMRPUSP). The study was approved by the Research Ethics Committee of HCFMRP-USP, process No. 2605/2010, and all the volunteers gave their free prior and written informed consent to participate in this study.

Data collection (duration of HIV infection, length of ART exposure, CD4+ T cell count, and viral load quantification) was performed by reviewing the patient records of HCFMRP-USP. The volunteers were divided, according to the use or not of different antiretroviral regimen, into the CG: 10 volunteers not in treatment; the $\mathrm{G}<2$ group: 20 volunteers treated with ART for up to 2 years; and the G>2 group: 20 volunteers treated with ART for more than 2 years.

\section{Anthropometric evaluation}

Weight and height were measured and the body mass index (BMI) was calculated using the formula (weight/height ${ }^{2}$ ) [10]. The patients were classified according to the recommendation of the World Health Organization (WHO) $[11,12]$. Body composition (lean mass and fat mass) was assessed by dual energy X-ray absorptiometry (DXA).

\section{Evaluation of bone mineral density}

Dual energy X-ray absorptiometry was used to evaluate the following bone sites: whole body, total hip, and lumbar spine, and was performed in the Radiology Department of HCFMRP-USP using a Hologic QDR 4500A scanner; Hologic Inc., Waltham, MA, USA. The bone mineral density evaluation was performed according to the classifications proposed by the WHO [13]. Standard procedures were adopted for the placement of the volunteers into the supine position during the examination phase, without metal objects or shoes. The examination was performed through a full-body scan of the patient.

\section{Biochemical analyses}

For the biochemical analyses, peripheral venous blood samples were collected after $12 \mathrm{~h}$ of fasting, and urine samples were taken from 24-h urine collections, collected on the 2nd morning. After collection, the blood samples were centrifuged and the serum obtained stored in a freezer at $-80{ }^{\circ} \mathrm{C}$ until the time of analysis. The urine samples were stored in a freezer at $-20{ }^{\circ} \mathrm{C}$ until the time of analysis.

The inflammatory markers, interleukin-6 (IL-6) and tumor necrosis factor alpha (TNF- $\alpha$ ), were determined with Luminex ${ }^{\circledR}$ equipment using a Milliplex ${ }^{\circledR}$ MAP Kit. The osteocalcin and PTH concentrations were measured using the immuno-chemiluminescence method (ICMA) with an IMMULITE $^{\circledR} 1000$ analyzer and the serum levels of $25-\mathrm{OH}$ vitamin D were determined by chemiluminescence (CLIA) using the LIAISON ${ }^{\circledR} 25-\mathrm{OH}$ vitamin D test. The serum albumin was determined by the colorimetric method, using Labtest ${ }^{\circledR}$ Kits. Quantification of CD4+ T lymphocytes was determined through flow cytometry using a Multitest ${ }^{\circledR}$ Kit, and quantification of viral load through chemiluminescence using a Versant ${ }^{\circledR}$ HIV-1 RNA 3.0 Kit. 
To determine the serum and urinary calcium concentrations, a mass spectrometer equipped with an inductively coupled plasma source was used (DRC-ICP-MS ELAN DRCII, Perkin Elmer, Sciex, Norwalk, CT, USA), operating with high purity argon (99.999 \%, Praxaair, Brazil).

The urinary deoxypyridinoline determination performed through the enzyme immunoassay method (ELISA) using a Quidel brand kit. The urinary creatinine analysis, used in the calculations for the correction of urinary deoxypyridinoline, was determined by the automated enzymatic method, using a WIENER ${ }^{\circledR}$ kinetic creatinine AA Kit in a BT 3000 Plus device.

The parameters of Young [14] were used as a reference for serum calcium, and those of Hodgkinson and Pyrah [15] for urinary calcium. The reference value of $25-\mathrm{OH}$ vitamin D $(\mathrm{ng} / \mathrm{mL})$ was provided by the Liaison ${ }^{\circledR}$ Kit for the North American population, considering $>150$ as excessive, $>30$ as sufficient, $10-30$ as insufficient, and $<10$ as deficient. The osteocalcin and PTH were calculated according to the reference value indicated by the Immulite $^{\circledR}$ Kit $(<2.0-21 \mathrm{ng} / \mathrm{mL})$ and $(12-65 \mathrm{pg} / \mathrm{mL})$ respectively. The urinary deoxypyridinoline according to the reference value indicated by the Quidel ${ }^{\circledR}$ kit (2.3$5.4 \mathrm{nmol} / \mathrm{mmol}$ ), and albumin according to the reference value of the Labtest ${ }^{\circledR}$ Kit $(3.5-5.5 \mathrm{~g} / \mathrm{dL})$. The reference values used for $\mathrm{CD} 4+\mathrm{T}$ lymphocytes were those published by the Ministry of Health [16]. Regarding the viral load quantification, undetectable viremia was considered for values less than 50 copies/mL HIV RNA, as proposed by the Versant ${ }^{\circledR}$ Kit.

\section{Dietary evaluation}

The dietary evaluation was performed by recording food intake over three days. Participants were instructed to fill out the forms immediately after eating to minimize errors and avoid possible underreporting. The dietary data obtained in household measures were converted to grams and milliliters to enable the chemical analysis of the food consumption and the information was processed through the Dietpro ${ }^{\circledR}$ version 5i nutritional analysis program [17]. The foods that were not included in the program were subsequently added, according to the database tables: Brazilian Food Composition Table (TACO) [18] and National Nutrient Database for Standard Reference (USDA) [19].

Energy consumption recommendations were obtained through the Melchior equation [20], and for macronutrients and calcium, the concepts proposed by the Dietary Reference Intakes (DRIs) were considered [21]. In the dietary evaluation the mean intake of macronutrients and calcium was considered, obtained from the three food records.

\section{Statistical analysis}

To describe the results obtained in the study in relation to the quantitative variables, the mean and standard deviation were calculated considering a $95 \%$ confidence level. The Kruskal-Wallis test was used to compare the groups in relation to the continuous variables and, in the cases where there was no difference between any pair of groups, Dunn's post test was performed. The Fisher's exact test was applied to determine the association between categorical variables and the groups. The Spearman's correlation coefficient $(r)$ was used to determine correlations.

To compare the groups with respect to the variables (urinary deoxypyridinoline, BMD of the femur, BMD of the lumbar spine, and BMD of the whole body), a method for selecting variables from a set of independent variables was first performed. The variable selection method used was the adjusted $R^{2}$, which selects a set of variables that present the highest adjusted $R^{2}$ for the regression model. From the set of selected variables, analysis of covariance (ANCOVA) was proposed. This methodology allows the ANOVA to incorporate one or more quantitative variables that present a linear relationship with the response variable. The results of the statistical analyzes were obtained using the SPSS 17.01 software program [22].

\section{Results}

The mean age of the participants of the $\mathrm{G}>2$ group was higher: $47.0 \pm 10.6$ years, and lower in those of the CG group: $30.8 \pm 9.4$ years. There was a significant difference in age between the $\mathrm{CG}$ and the $\mathrm{G}>2$ group, and between the $\mathrm{G}<2$ group and the $\mathrm{G}>2$ group $(p<0.05)$. The body mass index $\left(\mathrm{kg} / \mathrm{m}^{2}\right)$ was greater for the $\mathrm{G}<2$ group: $23.2 \pm 4.1$, and lower for the CG group: $20.4 \pm 6.7$, and according to the WHO BMI classification the volunteers presented normal weight. The percentage of fat mass was higher in the CG group: $24.9 \pm 7.5$ (Table 1).

The G>2 group presented a longer duration of HIV infection, undetectable viremia $(<50$ copies $/ \mathrm{mL})$, and an increased amount of CD4+ T cells $\left(\mathrm{mm}^{3}\right)$. There was a significant difference in the duration of HIV infection between the $C G$ and $\mathrm{G}<2$ groups and between the $C G$ the $G>2$ groups $(p<0.05)$. Furthermore, the $\mathrm{G}<2$ and $\mathrm{G}>2$ groups showed significant differences in the length of exposure to antiretroviral therapy treatment $(p<0.05$; Table 1$)$.

Osteoporosis was observed in lumbar spine bone site in the three groups, and according to the number of participants, the $\mathrm{G}>2$ group presented a higher percentage $(20 \%)$. Additionally, in total hip and whole body exams, only the participants of the $\mathrm{G}>2$ group presented with 
Table 1 General characteristics of HIV-seropositive patients according to study group

\begin{tabular}{|c|c|c|c|}
\hline Variables & Control group (CG) & Group < 2 years of ART $(\mathrm{G}<2)$ & Group $>2$ years of ART $(\mathrm{G}>2)$ \\
\hline$n$ & 10 & 20 & 20 \\
\hline Age (years) & $30.8 \pm 9.4^{\mathrm{a}}$ & $34.2 \pm 10.6^{\mathrm{a}}$ & $47.0 \pm 10.6^{\mathrm{b}}$ \\
\hline $\operatorname{BMI}\left(\mathrm{kg} / \mathrm{m}^{2}\right)$ & $20.4 \pm 6.7$ & $23.2 \pm 4.1$ & $22.9 \pm 2.6$ \\
\hline Fat mass $(\%)$ & $24.9 \pm 7.5$ & $23.8 \pm 6.8$ & $23.3 \pm 5.4$ \\
\hline Lean mass $(\%)$ & $69.4 \pm 7.0$ & $70.2 \pm 6.1$ & $71.6 \pm 5.2$ \\
\hline Duration of infection in months & $34.8 \pm 20.7^{\mathrm{a}}$ & $34.2 \pm 22.8^{\mathrm{a}}$ & $162.0 \pm 62.5^{\mathrm{b}}$ \\
\hline Time of exposure to ART in months & - & $10 \pm 6.7^{\mathrm{a}}$ & $127.2 \pm 54.3^{\mathrm{b}}$ \\
\hline NRTIs + NNRTIs-based ART [ $n(\%)]$ & - & $10(50)$ & $10(50)$ \\
\hline PIs + NRTIs-based ART [ $n(\%)]$ & - & $10(50)$ & $10(50)$ \\
\hline TDF (NRTIs)-based ART [ $n(\%)]$ & - & $11(55)$ & $7(35)$ \\
\hline Undetectable VL (\%) & 12.5 & 70 & 100 \\
\hline $\mathrm{CD} 4+\left(\right.$ cells $\left./ \mathrm{mm}^{3}\right)$ & $521.9 \pm 82.6$ & $424.1 \pm 275.8^{\mathrm{a}}$ & $593.1 \pm 234.7^{b}$ \\
\hline Lumbar spine $T$ score & $-0.7 \pm 0.9$ & $-0.9 \pm 0.8$ & $-1.1 \pm 0.8$ \\
\hline Osteopenia $[n(\%)]$ & $3(30)$ & $9(45)$ & $7(35)$ \\
\hline Osteoporosis $[n(\%)]$ & $1(10)$ & $1(5)$ & $4(20)$ \\
\hline Hip total $T$ score & $-0.51 \pm 0.6$ & $-0.33 \pm 0.9^{\mathrm{a}}$ & $-0.95 \pm 0.78^{\mathrm{b}}$ \\
\hline Osteopenia $[n(\%)]$ & $2(20)$ & $4(20)$ & $6(30)$ \\
\hline Osteoporosis $[n(\%)]$ & - & - & $2(10)$ \\
\hline Whole-body $T$ score & $-0.7 \pm 0.8$ & $-0.6 \pm 0.8$ & $-0.9 \pm 0.7$ \\
\hline Osteopenia $[n(\%)]$ & $4(40)$ & $8(40)$ & $11(55)$ \\
\hline Osteoporosis $[n(\%)]$ & - & - & $2(10)$ \\
\hline
\end{tabular}

Kruskal-Wallis test. Values are reported as mean $\pm \mathrm{SD}$

$B M I$ body mass index, ART antiretroviral therapy, NRTIs nucleoside analog reverse-transcriptase inhibitors, NNRTIS non-nucleoside analog reverse-transcriptase inhibitors, $P I s$ protease inhibitors, $T D F$ tenofovir, $V L$ viral load; undetectable VL: $<50 \mathrm{copies} / \mathrm{mL}$

a, b, c Different letters indicate $p<0.05$

osteoporosis $(10 \%)$. The percentage of osteopenia in the whole body was lower for the participants of the CG and $\mathrm{G}<2$ groups $(40 \%)$, whereas it was $55 \%$ in the $\mathrm{G}>2$ group. A significant difference was also observed in total hip BMD between the two groups on antiretroviral treatment $(p<0.05$; Table 1).

Regarding the laboratory parameters, the serum concentrations of PTH, calcium, albumin, and the bone formation marker osteocalcin presented values within normal limits. Calcemia was within normal limits, except for in the CG group: $8.5 \pm 0.6 \mathrm{mg} / \mathrm{dL}$, which showed a value slightly below the normal reference, with a significant difference between the CG and G>2 groups, as well as between the $\mathrm{G}<2$ and $\mathrm{G}>2$ groups $(p<0.05)$. The bone reabsorption marker urinary deoxypyridinoline presented in increased values in all the groups, with a significant difference between the $\mathrm{CG}$ and $\mathrm{G}<2$ groups $(p<0.05)$. The $25-\mathrm{OH}$ vitamin $\mathrm{D}$ levels were below the acceptable limits in all groups (Table 2). When considering all participants $(n=50), 34 \%$ presented with insufficient vitamin $\mathrm{D}$ values and $22 \%$ with deficiency, with the lowest vitamin D serum value being for the group with longer exposure to ART.
The proinflammatory markers, IL- 6 and TNF- $\alpha$, presented with the highest mean in the HIV seropositive group (CG), with a lower mean for the group with longer exposure to the antiretroviral treatment $(\mathrm{G}>2)$. The TNF- $\alpha$ values presented a significant different between the $\mathrm{CG}$ and $\mathrm{G}>2$ groups, as well as between the $\mathrm{G}<2$ and $\mathrm{G}>2$ groups ( $p<0.05$; Table 2). Evaluating all the participants and grouping them by detectable versus undetectable viral load (data not shown in tables), the mean IL-6 values of $0.9 \pm 1.1$ and $0.7 \pm 1.0 \mathrm{pg} / \mathrm{mL}$ and mean TNF- $\alpha$ values of $15.2 \pm 6.5$ and $12.0 \pm 6.3 \mathrm{pg} / \mathrm{mL}$, respectively, were found, with no significant association independent of viral load.

Regarding food consumption, the groups mostly demonstrated inappropriate consumption, with the intake of energy, carbohydrates, and protein greater than the need, and fat intake for the $\mathrm{G}<2$ group equal to the recommendation and for the $\mathrm{G}>2$ group lower than the recommendation. All groups presented inadequate calcium intakes. There was a significant difference only for fat intake between the $\mathrm{CG}$ and $\mathrm{G}<2$ groups $(p<0.05$; Table 3$)$. The significant correlations of BMD with BMI, 25-OH vitamin D, and calcium are shown in Table 4 . When the urinary deoxypyridinoline values were correlated with the continuous variables 
Table 2 Comparisons between serum and urinary biochemical concentrations according to study group

\begin{tabular}{lccc}
\hline Variables & Control group $(\mathrm{CG})$ & Group $<2$ years of ART $(\mathrm{G}<2)$ & Group $>2$ years of ART $(\mathrm{G}>2)$ \\
\hline DPD $(\mathrm{nmol} / \mathrm{mmol})$ & $7.5 \pm 2.3^{\mathrm{a}}$ & $9.7 \pm 2.9^{\mathrm{b}}$ & $8.5 \pm 3.0$ \\
Osteocalcin $(\mathrm{ng} / \mathrm{mL})$ & $0.5 \pm 0.3$ & $0.4 \pm 0.2$ & $0.6 \pm 0.9$ \\
PTH $(\mathrm{pg} / \mathrm{mL})$ & $18.8 \pm 13.6$ & $16.1 \pm 10.9$ & $24.9 \pm 19.7$ \\
$25 \mathrm{OH}$ vitamin D $(\mathrm{ng} / \mathrm{mL})$ & $29.0 \pm 11.3$ & $29.1 \pm 9.5$ & $26.8 \pm 7.7$ \\
TNF- $\alpha(\mathrm{pg} / \mathrm{mL})$ & $16.8 \pm 8.8^{\mathrm{a}}$ & $14.0 \pm 4.3^{\mathrm{a}, \mathrm{b}}$ & $10.0 \pm 5.9^{\mathrm{c}}$ \\
IL-6 $(\mathrm{pg} / \mathrm{mL})$ & $1.0 \pm 1.1$ & $0.8 \pm 0.9$ & $0.5 \pm 1.0$ \\
Total calcium $(\mathrm{mg} / \mathrm{dL})$ & $8.5 \pm 0.6^{\mathrm{a}}$ & $8.7 \pm 0.7^{\mathrm{a}, \mathrm{b}}$ & $9.3 \pm 1.0^{\mathrm{c}}$ \\
Urinary calcium $(\mathrm{mg} / \mathrm{kg} / 24 \mathrm{~h})$ & $1.3 \pm 0.6$ & $1.1 \pm 0.8$ & $1.3 \pm 0.8$ \\
Albumin $(\mathrm{mg} / \mathrm{dL})$ & $4.0 \pm 0.3$ & $4.1 \pm 0.6$ & $3.9 \pm 0.6$
\end{tabular}

Kruskal-Wallis test. Values are reported as mean \pm SD

$A R T$ antiretroviral therapy, $D P D$ urinary deoxypyridinoline, $P T H$ parathormone intact molecule, $T N F-\alpha$ tumor necrosis factor alpha, $I L-6$ interleukin-6

a, b Different letters indicate $p<0.05$

Table 3 Food intake values energy, macronutrient, and calcium intake according to study group

\begin{tabular}{lccc}
\hline Variables & Control group $(\mathrm{CG})$ & Group $<2$ years of ART $(\mathrm{G}<2)$ & Group $>2$ years of ART $(\mathrm{G}>2)$ \\
\hline Energy (kcal) & $2139.3 \pm 621.1$ & $1843.0 \pm 474.2$ & $2096.6 \pm 1027.7$ \\
Recommendation & $1787.8 \pm 133.0$ & $1766.8 \pm 268.9$ & $1740.0 \pm 195.1$ \\
CHO $(\mathrm{g})$ & $290.8 \pm 113.2$ & $260.8 \pm 88.9$ & $295.8 \pm 160.2$ \\
Recommendation & $245.8 \pm 18.3$ & $242.9 \pm 37.0$ & $293.3 \pm 26.8$ \\
Protein (g) & $118.5 \pm 51.7$ & $107.4 \pm 57.1$ & $125.1 \pm 68.9$ \\
Recommendation & $67.0 \pm 5.0$ & $66.3 \pm 10.1$ & $65.3 \pm 7.3$ \\
Lipids (g) & $62.7 \pm 17.1^{\mathrm{a}}$ & $48.7 \pm 14.3^{\mathrm{b}}$ & $53.5 \pm 30.9$ \\
Recommendation & $59.6 \pm 4.4$ & $48.7 \pm 9.0$ & $58.0 \pm 7.3$ \\
Calcium (mg) & $642.9 \pm 218.3$ & $684.6 \pm 315.3$ & $786.7 \pm 400.2$ \\
Recommendation & 800 & 800 & 800 \\
\hline
\end{tabular}

Kruskal-Wallis test. Values are reported as mean $\pm \mathrm{SD}$

$A R T$ antiretroviral therapy, $\mathrm{CHO}$ carbohydrates, in grams. Recommendation: Dietary Reference Intakes

a, b Different letters indicate $p<0.05$

(data not shown in table) significant correlations were found with IL-6 $(r=-0.29, p<0.05)$, and serum calcium $(r=0.37 ; p<0.05)$.

Table 5 presents the results of linear regression models that were adjusted between the groups to check the possible influence that the variables (age, BMI, fat mass, lean mass, duration of HIV infection, length of exposure to antiretroviral therapy, calcium and protein intake, and serum and urinary biochemical markers) had on the bone health indicators evaluated: urinary deoxypyridinoline, total hip BMD, lumbar spine BMD, and whole body BMD.

\section{Discussion}

An interesting aspect was observed in our study in that the individuals infected with HIV and not using ART presented with higher serum levels of inflammatory markers than the individuals in treatment, affirming that the initial phase of infection may be characterized by an increased production of proinflammatory cytokines and their persistence throughout the natural course of the disease, even in the presence of an effective suppression of viral replication with antiretroviral therapy [1, 23]. It was noted that the group with shorter exposure time to ART and to HIV infection presented with higher serum inflammatory marker values than the group with longer treatment time; most likely this could be due to detectable viremia that directly contributed to the activation of $\mathrm{T}$ cells and the release of proinflammatory cytokines [1].

Interestingly, some cytokines (both anti- and pro-inflammatory, such as IL-3, IL-4, IL-10, TGF- $\beta$ and IL-1, IL-6, IL-12, IL-17, IFN-y, TNF- $\alpha$, respectively) are involved in the regulation of bone remodeling with a crucial role in 
Table 4 Spearman's correlation between the quantitative variables and bone densitometry of the study groups

\begin{tabular}{|c|c|c|c|c|c|c|}
\hline Variables & Total hip BMD & $p^{*}$ & Lumbar spine BMD & $p^{*}$ & Whole-body BMD & $p^{*}$ \\
\hline Age (years) & -0.24 & 0.08 & -0.01 & 0.93 & -0.24 & 0.08 \\
\hline $\operatorname{BMI}\left(\mathrm{kg} / \mathrm{m}^{2}\right)$ & 0.42 & $<0.01$ & 0.10 & 0.47 & 0.01 & 0.94 \\
\hline Fat mass $(\%)$ & -0.11 & 0.42 & 0.07 & 0.62 & -0.20 & 0.15 \\
\hline Lean mass $(\%)$ & 0.10 & 0.47 & -0.06 & 0.65 & 0.18 & 0.19 \\
\hline $\mathrm{DPD}(\mathrm{nmol} / \mathrm{mmol})$ & -0.04 & 0.75 & -0.20 & 0.14 & -0.01 & 0.97 \\
\hline PTH $(\mathrm{pg} / \mathrm{mL})$ & -0.01 & 0.94 & 0.15 & 0.28 & -0.10 & 0.44 \\
\hline $25 \mathrm{OH}$ vitamin $\mathrm{D}(\mathrm{ng} / \mathrm{mL})$ & -0.16 & 0.24 & -0.37 & $<0.01$ & 0.15 & 0.28 \\
\hline TNF- $\alpha(\mathrm{pg} / \mathrm{mL})$ & -0.01 & 0.95 & 0.07 & 0.58 & 0.08 & 0.53 \\
\hline IL-6 (pg/mL) & -0.23 & 0.10 & -0.01 & 0.89 & 0.07 & 0.58 \\
\hline Total calcium (mg/dL) & -0.19 & 0.17 & -0.22 & 0.11 & -0.12 & 0.37 \\
\hline Urinary calcium $(\mathrm{mg} / \mathrm{kg} / 24 \mathrm{~h})$ & -0.01 & 0.90 & -0.27 & 0.05 & 0.14 & 0.29 \\
\hline $\mathrm{CD} 4+\left(\right.$ cells $\left./ \mathrm{mm}^{3}\right)$ & -0.02 & 0.87 & $<-0.01$ & 0.99 & 0.07 & 0.60 \\
\hline PTN consumption $(\mathrm{g})$ & 0.14 & 0.31 & 0.13 & 0.33 & 0.22 & 0.11 \\
\hline Calcium consumption (mg) & 0.23 & 0.10 & -0.10 & 0.45 & 0.11 & 0.43 \\
\hline Duration of infection & -0.14 & 0.32 & 0.04 & 0.77 & 0.03 & 0.80 \\
\hline Time of exposure to ART & -0.12 & 0.37 & -0.07 & 0.62 & -0.24 & 0.08 \\
\hline
\end{tabular}

$B M D$ total bone mineral density in $\mathrm{g} / \mathrm{cm}^{2}, B M I$ body mass index, $T N F-\alpha$ tumor necrosis factor alpha, $I L-6$ interleukin- $6, P T N$ protein; Duration of infection in months; Time of exposure to ART in months, $A R T$ antiretroviral therapy

* Significant values: $p<0.05$

Table 5 Linear regression models for total hip bone densitometry values (model I), for bone densitometry values of the lumbar spine (model II), for whole-body bone densitometry values (model III), and for urinary deoxypyridinoline biochemical values (model IV)

\begin{tabular}{|c|c|c|c|c|c|c|}
\hline \multirow[t]{2}{*}{ Model } & \multirow[t]{2}{*}{ Parameters } & \multirow[t]{2}{*}{ Estimate } & \multirow[t]{2}{*}{$p$ value } & \multicolumn{2}{|l|}{$95 \% \mathrm{CI}$} & \multirow[t]{2}{*}{$R^{2}$} \\
\hline & & & & LL & UL & \\
\hline \multirow[t]{4}{*}{ I } & Age (years) & -0.005 & $<0.001$ & -0.007 & -0.003 & \multirow[t]{4}{*}{0.47} \\
\hline & $\operatorname{BMI}\left(\mathrm{kg} / \mathrm{m}^{2}\right)$ & 0.013 & $<0.001$ & 0.006 & 0.019 & \\
\hline & IL-6 (pg/mL) & -0.018 & 0.18 & -0.045 & 0.009 & \\
\hline & Calcium consumption (mg) & $<0.001$ & 0.13 & $<0.001$ & $<0.001$ & \\
\hline \multirow[t]{3}{*}{ II } & $25 \mathrm{OH}$ vitamin $\mathrm{D}(\mathrm{ng} / \mathrm{mL})$ & -0.004 & $<0.001$ & -0.007 & -0.001 & \multirow[t]{3}{*}{0.25} \\
\hline & Total calcium (mg/dL) & -0.032 & $<0.05$ & -0.061 & -0.003 & \\
\hline & Urinary calcium $(\mathrm{mg} / \mathrm{kg} / 24 \mathrm{~h})$ & -0.013 & 0.41 & -0.046 & 0.019 & \\
\hline \multirow[t]{2}{*}{ III } & Time of exposure to ART & 0.0004 & 0.05 & -0.0007 & 0.0002 & \multirow[t]{2}{*}{0.13} \\
\hline & PTN consumption (g) & 0.0004 & 0.07 & -0.00004 & 0.001 & \\
\hline \multirow[t]{3}{*}{ IV } & Duration of infection & -0.012 & $<0.05$ & -0.023 & -0.002 & \multirow[t]{3}{*}{0.25} \\
\hline & IL-6 (pg/mL) & -0.502 & 0.21 & -1.295 & 0.292 & \\
\hline & Urinary calcium (mg/kg/24 h) & 1.306 & 0.01 & 0.258 & 2.355 & \\
\hline
\end{tabular}

The linear regression model I; II and III were adjusted according to serum concentration variables. Statistically significant: $p<0.05$

$C I$ confidence interval, $L L$ lower limit, $U L$ upper limit, $R^{2}$ coefficient of variation, $B M I$ body mass index, $I L-6$ interleukin-6, $\mathrm{Ca}$ calcium, PTN protein time of exposure to ART in months; Duration of infection in months inhibiting and stimulating the activity of bone cells [24], and in this study the evaluated proinflammatory cytokines (TNF- $\alpha$, IL-6) demonstrated the ability to stimulate osteoclast activity via the results observed in the bone resorption marker values, mainly viremic groups.

At the same time it was observed that the persistent inflammation mediated by HIV and the toxicity of long-term ART use contributed to the increase in the bone reabsorption markers, directly affecting bone mass, especially for the group with the longest exposure to the virus and antiretrovirals. When analyzing the coefficients of determination $\left(R^{2}\right)$ of the linear regression models it was observed that the length of HIV infection exposure had significant influence over the bone reabsorption marker, 
with a tendency for reduced urinary deoxypyridinoline levels.

Despite the evidence of adverse effects of antiretroviral drug regimens, principally in use of tenofovir (TDF), which lead to reduced bone mineral density due to the alterations in metabolism of vitamin $\mathrm{D}$ and phosphate and in osteoblast function [25], this evidence was not associated in our study due to a limited number of patients undergoing treatment with TDF.

In a cross-sectional study, high levels of IL-6 were detected in HIV-infected individuals compared with uninfected subjects, with a significant correlation between the quantification of the viral load in patients and advanced HIV disease [26]. Another recent study found higher levels of plasma IL-6 in HIV-infected subjects when their viral load quantification was elevated [23], which draws attention to the data presented here: despite presenting no significant correlation between IL- 6 and the increase of viremia, our data showed increased IL-6 values in HIV-infected participants with detectable viremia compared to the infected individuals with undetectable viremia.

Regarding TNF- $\alpha$, a recent study showed a significant association between elevated TNF- $\alpha$ levels and increased risk of progression to AIDS, even after adjustment for antiretroviral treatment, CD4+ T lymphocyte count, and viral load quantification. Furthermore, the study found that the increased levels of inflammatory markers were independently associated with an increased risk of AIDS events versus non-AIDS events [27]. In the present study an increase was observed in the amounts of TNF- $\alpha$ in the group with detectable viremia compared to the group with undetectable viremia, with this finding being similar to another study that showed increased viral load in acute HIV infection associated with elevations in plasma levels of several cytokines, including a rapid rise in TNF- $\alpha$ [28].

Overproduction of proinflammatory cytokines such as IL- 6 , TNF- $\alpha$, and others can stimulate the activity of bonereabsorbing cells, affecting bone remodeling and leading to bone metabolism dysfunction [4]. Similar results were identified in the present study, with reduced bone mineral density at different skeletal sites and greater involvement in the whole-body bone site. A preclinical model developed in Erlangen showed high levels of HIV viral proteins and inflammatory cytokines, such as IL- 6 and TNF- $\alpha$, associated with increased osteoclast activity, considered to be one of the factors implicated in reduced bone mineral density in HIV-infected patients [29].

However, in the linear regression models for the bone densitometry values there was a reduction in femoral BMD when the effect of age was analyzed $(p<0.001)$, unlike the BMI, that showed a tendency to increase the femoral BMD values $\left(1 \mathrm{~kg}\right.$ each $/ \mathrm{m}^{2}$ led to an increase of $0.013 \mathrm{~g} /$ $\mathrm{cm}^{2}$ BMD of the femur, $\left.p<0.001\right)$. For the lumbar BMD, a decrease in value was found when the effect of $25-\mathrm{OH}$ vitamin $\mathrm{D}(p<0.01)$ and total calcium $(p<0.05)$ were analyzed, whereas for the whole body BMD, only the length of exposure to antiretroviral therapy showed a significant influence on bone mass $(p=0.05)$.

A study carried out in Bologna showed that proinflammatory cytokines, such as IL- 6 and TNF- $\alpha$, promoted an increase of osteoclastogenesis and bone reabsorption, and that high concentrations of HIV RNA were associated with elevated concentrations of RANKL (receptor activator of nuclear factor kappa-B ligand) [30]. Other studies have shown that exposure to ART results in a disturbance of the metabolism of amino acids directly into osteoblasts and osteoclasts, altering bone homeostasis, as well as the presence of mitochondrial dysfunction, thus contributing to an inflammatory process and consequently to the loss of bone mass [31, 32]. It is important to emphasize that many factors can influence the activities of osteoblasts and osteoclasts or calcium homeostasis and calciotropic hormones, such as parathyroid hormone and vitamin D [33].

In this study, despite PTH values being within normal limits in all groups, it was observed that the group with longer exposure to both the treatment and HIV infection had higher PTH and bone reabsorption marker values and lower levels of IL-6, which may be justified due to better viremic control [1]. Furthermore, all groups of this study showed insufficient serum levels of vitamin $\mathrm{D}$, even though it is known that a reduction in vitamin D affects its role as an inhibitor in the production of PTH and reduces absorption of calcium from the intestinal tract, favoring the reduction of bone mass [34].

We did not detect alterations in other factors (low body weight, advanced age, hypercalciuria, and low CD4+ T cell count) that could contribute to reduced bone mass. However, the mean values of calcium and protein intake were, respectively, low and high in the three groups. It is necessary to take into consideration that the age of the group with longer exposure to antiretroviral therapy was higher than the age of the other two groups [35]. Nonetheless, the mean age of the $\mathrm{G}>2$ was $<50$ years and these subjects showed a high frequency of osteoporosis. Therefore, it is important to call attention to the fact that even with control of viremia through the use of antiretrovirals, inflammation persists and its chronic effects may contribute to bone loss [36].

The present study showed an increase in the production of proinflammatory cytokines, most notably in the untreated group, due to their higher levels and greater number of copies of HIV RNA, and that the inflammation persisted throughout the antiretroviral treatment, as observed in the other groups. The increased levels of 
urinary deoxypyridinoline mainly observed in the group with longer ART resulted in greater losses of bone mineral density of the whole body.

However, even in the presence of a suppression of viral replication through highly active antiretroviral therapy, chronic activation of the innate immune system persists, releasing proinflammatory cytokines and contributing to the increased risk of metabolic complications and the emergence of multiple morbidities. Thus, it is extremely important to conduct longitudinal studies to better detect damage in various tissues due to the persistence of inflammation over time, aiming to prevent harm and restore the health of HIV-infected individuals.

Acknowledgments The authors would like to thank the Special Treatment Unit for Infectious Diseases of the Clinical Hospital of Ribeirão Preto, University of São Paulo, Brazil; the Foundation for the Support of Teaching, Research and Service-FAEPA of HCRPFMRP; the Clinical Research Unit-UPC of HCRP-FMRP for supporting this research and the Sao Paulo Research Foundation (FAPESP) Grant\#2013/11535-2 and Grant\#2013/10765-4 for the support provided to Dr. Anderson Marliere Navarro and Erika Grasiela Marques de Menezes. Dr. Francisco José Albuquerque de Paula received a grant from $\mathrm{CNPq}(306027 / 2011-9)$. The authors are in debt to all the volunteers that participated in the study.

\section{Compliance with ethical standards}

Conflict of interest All authors have no conflicts of interest to declare.

\section{References}

1. Deeks SG, Tracy R, Douek DC (2013) Systemic effects of inflammation on health during chronic HIV infection. Immunity 39:633-645

2. French MA, King MS, Tschampa JM, Silva BA, Landay AL (2009) Serum immune activation markers are persistently increased in patients with HIV infection after 6 years of antiretroviral therapy despite suppression of viral replication and reconstitution of CD4 + T cells. J Infect Dis 200:1212-1215

3. Walker HV, Brown TT (2012) Bone loss in the HIV-infected patient: evidence, clinical implications, and treatment strategies. J Infect Dis 205:391-398

4. Hashizume M, Hayakawa N, Mihara M (2008) IL-6 transsignalling directly induces RANKL on fibroblast-like synovial cells and is involved in RANKL induction by TNF- $\alpha$ and IL-17. Rheumatology 47:1635-1640

5. Caron DM, Lagathu C, Boccara F, Vigouroux C, Capeau J (2010) HIV-associated lipodystrophy: from fat injury to premature aging. Trends Mol Med 16:218-229

6. Orwig DL, Chiles N, Jones M, Hochberg MC (2011) Osteoporosis in men: update. Rheum Dis Clin N Am 37:401-414

7. Mackiewicz Z, Niklinska WE, Kowalewska J, Chyczewski L (2011) Bone as a source of organism vitality and regeneration. Folia Histochem Cytobiol 49:558-569

8. Tien PC, Choi AI, Zolopa AR, Benson C, Tracy R, Scherzer R, Bacchettip P, Shlipak M, Grunfeld C (2010) Inflammation and mortality in HIV-infected adults: analysis of the FRAM study cohort. J Acquir Immune Defic Syndr 55:316-322
9. Freiberg MS, Chang CC, Kuller LH, Skanderson M, Lowy E, Kraemer AA et al (2013) HIV infection and the risk of acute myocardial infarction. JAMA Intern Med 173:614-622

10. WHO-World Health Organization. BMI classification. http:// apps.who.int/bmi/. Accessed 2 April 2014

11. Harrison GGBE, Lindsay CJE, Johnston FE, Lohman TG, Pollock ML, Roche AF, Wilmore J (1988). Skinfold thicknesses and measurement technique. In: Lohman TG, Roche AF, Martorell RI (eds) Anthropometric standardisation reference manual. Human Kinetics, Champaign, pp 55-70

12. WHO. World Health Organization (1995) Physical status: the use and interpretation of anthropometry. Report of a WHO expert committee. Organization WH

13. WHO-World Health Organization (1994) Assessment of fracture risk and its application to screening for postmenopausal osteoporosis. WHO technical report series

14. Young DS (1987) Implementation of SI units for clinical laboratory data. Ann Intern Med 106:114-129

15. Hodgkinson A, Pyrah LN (1958) The urinary excretion of calcium and inorganic phosphate in 344 patients with calcium stone of renal origin. Br J Surg 46:10

16. Brasil. Ministério da Saúde: Contagem de células T CD4 + e testes de carga viral: principais marcadores laboratoriais para indicação e monitorização ao tratamento anti-retroviral. http:// bvsms.saude.gov.br/bvs/publicacoes/16contagem_celulasTCDA. pdf. Accessed 4 April 2014

17. Diet PRO (1997) Software de avaliação nutricional e prescrição dietética. UFV. Viçosa, MG, Brasil. A. S. Sistema

18. TACO_Tabela Brasileira de Composição de AlimentoS 4a. edição. http://www.unicamp.br/nepa/taco/tabela/. Accessed 10 March 2014

19. USDA National Nutrient Database for Standard Reference. http://www.ars.usda.gov/ba/bhnrc/ndl. Accessed 10 March 2014

20. Melchior JC, Raguin G, Boulier A, Bouvet E, Rigaud D, Matheron S, Casalino E, Vilde JL, Vachon F, Coulaud JP (1993) Resting energy expenditure in human immunodeficiency virusinfected patients: comparison between patients with and without secondary infections. Am J Clin Nutr 57:614-619

21. DRIs-Dietary Reference Intakes for Energy, Carbohydrate, Fiber, Fat, Fatty Acids, Cholesterol, Protein, and Amino Acids. Institute of Medicine (2005). http://www.nap.edu/catalog. php?record_id=10490\#orgs. Accessed 10 March 2014

22. SPSS 17.0 for windows [computer program] (2008). Statistical Package for Social Science (SPSS). Release Version 17.0.1. Chicago (IL), SPSS Incorporation

23. Nasi M, Pinti M, Mussini C, Cossarizza A (2014) Persistent inflammation in HIV infection: established concepts, new perspectives. Immunol Lett. doi:10.1016/j.imlet.2014.01.008

24. Pietschmann P, Mechtcheriakova D, Meshcheryakova A, FogerSamwald U, Ellinger I (2015) Immunology of osteoporosis: a mini-review. Gerontology. doi:10.1159/000431091

25. Woodward CL, Hall AM, Williams IG, Madge S, Copas A, Nair $\mathrm{D}$ et al (2009) Tenofovir-associated renal and bone toxicity. HIV Med 10:482-487

26. Lederman M, Kalish LA, Asmuth D, Fiebig E, Mileno M, Busch MP (2000) Modeling relationships among HIV-1 replication, immune activation and CD4 + T-cell losses using adjusted correlative analyses. AIDS 14:951-958

27. McComsey GA, Kitch D, Sax PE, Tierney C, Jahed NC, Melbourne K, Ha B, Brown TT, Bloom A, Fedarko N, Daar ES (2014) Associations of inflammatory markers with AIDS and non-AIDS clinical events after initiation of antiretroviral therapy: AIDS clinical trials group A5224 s, a substudy of ACTG A5202. J Acquir Immune Defic Syndr 65:167-174

28. Stacey AR, Norris PJ, Qin L, Haygreen EA, Taylor E, Heitman J, Lebedeva M, Decamp A, Li D, Grove D, Self SG, Borrow P 
(2009) Induction of a striking systemic cytokine cascade prior to peak viremia in acute human immunodeficiency virus type 1 infection, in contrast to more modest and delayed responses in acute hepatitis B and C virus infectious. J Virol 83:3719-3733

29. Axmann R, Bohm C, Kronke G, Zwerina J, Smolen J, Schett G (2009) Inhibition of interleukin-6 receptor directly blocks osteoclast formation in vitro and in vivo. Arthritis Rheum 60:2747-2756

30. Gibellini D, Borderi M, de Crignis E, Cicola R, Vescini F, Caudarella R, Chiodo F, Re MC (2007) RANKL/OPG/TRAIL plasma levels and bone mass loss evaluation in antiretroviral naive HIV-1-positive men. J Med Virol 79:1446-1454

31. Mansky KC (2010) Aging, human immunodeficiency virus, and bone health. Clin Interv Aging 23:285-292

32. Gerschenson M, Kim C, Berzins B, Taiwo B, Libutti DE, Choi J, Chen D, Weinstein J, Shore J, da Silva B, Belsey E, McComsey
GA, Murphy RL (2009) Mitochondrial function, morphology and metabolic parameters improve after switching from stavudine to a tenofovir-containing regimen. J Antimicrob Chemother 63:1244-1250

33. Eriksen EF (2010) Cellular mechanisms of bone remodeling. Rev Endocr Metab Disord 11:219-227

34. Rosenvinge MM, Gedela K, Copas AJ, Wilkinson A, Sheehy CA, Bano G, Hay PE, Pakianathan MR, Sadiq ST (2010) Tenofovirlinked hyperparathyroidismis independently associated with the presence of vitamin D deficiency. J Acquir Immune Defic Syndr 54:496-499

35. Martini LA (2006) Cálcio e Fósforo (cap. 14). In: Cardoso MA (ed) Nutrição e Metabolismo. Guanabara Koogan, Rio de Janeiro, pp 219-228

36. Brown TT (2011) The effects of HIV-1 infection on endocrine organs. Best Pract Res Clin Endocrinol Metab 25:403-413 